AWEJ for Translation \& Literary Studies, Volume3, Number3. August 2019

DOI: http://dx.doi.org/10.24093/awejtls/vol3no3.13

Pp.165-177

\title{
Identity Malaise of Exiled characters in Ethnic Fiction \\ Case study: Mohja Kahf's The Girl in the Tangerine Scarf (2006)
}

\author{
Fadia Boualem \\ Department of English, \\ Djillali Liabes University, Sidi Bel Abbes- Algeria \\ Noureddine Guerroudj \\ Department of English \\ Djillali Liabes University, Sidi Bel Abbes- Algeria
}

\begin{abstract}
This paper presents a critical study of how a contemporary ethnic writer presents exile cases and counter-hegemonic discourses throughout it as regards to notions of belonging and identity. The process of identity-making is discussed through an examination of the protagonist's development in The Girl in the Tangerine Scarf (2006). This study focuses on how the protagonist constructs a new meaning of exile that challenges previous conventions and seeks to recuperate the sense of pride in cultural difference. It also attempts to highlight how this literary work is a counternarrative regarding the cultural practices that hitherto have been regarded as archaic; backward; and yet fit to adapt the new changes of the Western World.
\end{abstract}

Keywords: belonging, dislocation, ethnic fiction, exile, home, identity, Mohja Kahf

Cites as: Boualem, F., \& Guerroudj, N. (2019). Identity Malaise of Exiled characters in Ethnic Fiction Case study: Mohja Kahf's The Girl in the Tangerine Scarf (2006). Arab World English Journal for Translation \& Literary Studies, 3 (3) 175-187.

DOI: http://dx.doi.org/10.24093/awejtls/vol3no3.13 